\title{
Public health status of Myanmar refugees in South East Asia: A Malaysian case study
}

\author{
Mohd Hanapi, I.R. ${ }^{1}$, Sahimin, N. ${ }^{2}$, Lewis, J.W. ${ }^{3}$, Lau, Y.L. ${ }^{4}$, Othman, J. ${ }^{5}$, Tedong, P.A. ${ }^{6}$, Mohd Zain, S.N. ${ }^{1 *}$ \\ ${ }^{1}$ Institute of Biological Sciences, Faculty of Science, Universiti Malaya, 50603 Kuala Lumpur, Malaysia \\ ${ }^{2}$ Tropical Infectious Diseases Research and Education Centre (TIDREC), Universiti Malaya, 50603 Kuala Lumpur, Malaysia \\ ${ }^{3}$ School of Biological Sciences, Royal Holloway, University of London, TW20 OEX Egham, Surrey United Kingdom \\ ${ }^{4}$ Department of Parasitology, Faculty of Medicine, Universiti Malaya, 50603 Kuala Lumpur, Malaysia \\ ${ }^{5}$ Department of Language \& Literacy Education, Faculty of Education, Universiti Malaya, 50603 Kuala Lumpur, Malaysia \\ ${ }^{6}$ Department of Urban \& Regional Planning, Faculty of Built Environment, Universiti Malaya, 50603 Kuala Lumpur, Malaysia \\ *Corresponding author: nsheena@um.edu.my
}

\section{ARTICLE HISTORY}

Received: 22 November 2021 Revised: 8 December 2021 Accepted: 8 December 2021 Published: 31 December 2021

\begin{abstract}
The United Nations High Commissioner for Refugees (UNHCR) reports over 80 million people are displaced worldwide with approximately 26.3 million categorized as refugees and over a million residing temporarily in South East Asia. Despite the lack of national legislative framework in place for refugees and asylum seekers (RAS), Malaysia hosts approximately 178,140 as registered with UNHCR and the majority originate from Myanmar. In this review, we examine refugees from South East Asia, particularly from Myanmar that have contributed to the largest influx of refugees to this region with a focus on their health status. The present study traces barriers to the health care of refugees in the country of asylum and also the challenges faced by these communities in accessing health services.
\end{abstract}

Keywords: health; refugees; asylum seekers; Myanmar; Malaysia.

\section{INTRODUCTION}

A refugee is a person who, according to the Article 1, 1951 Convention on Refugees, resides outside his/her country of nationality or habitual residence and has a well-founded fear of persecution due to race, religion, nationality and membership of a particular social or political group. A refugee is also unable or unwilling to avail himself/herself to protection within that country or to return there, for fear of persecution. Therefore, individuals in this category require basic rights to independence, protection, family life, safety and freedom of movement. While Article 23 of the Refugee Convention and Article 25 of the Universal Declaration of Human Rights guarantee the rights of refugees not only to access services for physical and mental health but also education and justice (UNHCR, 2010).

According to the United Nations High Commissioner for Refugees (UNHCR), global forced displacement has surpassed 82 million at the end of 2020 with 26.4 million being refugees (UNHCR, 2021a). Over half the numbers originate from five countries such as the Syrian Arab Republic $(6,700,000)$, Venezuela $(4,000,00)$, Afghanistan $(2,600,00)$, South Sudan $(2,200,000)$ and Myanmar $(1,100,000)$. Approximately $39 \%$ of refugees worldwide reside in Turkey $(3,700,000)$ followed by Colombia $(1,700,000)$, Pakistan $(1,400,000)$, Uganda $(1,400,000)$ and Germany $(1,200,000)$.
Countries such as Malaysia, Bangladesh, Thailand and Indonesia have not ratified the 1951 Refugee Convention relating to the status of refugees and the 1967 protocol. However, due to humanitarian grounds, these countries, which have a long tradition of hosting refugees continue to host them. The lack of a legal framework to manage RAS results in limited access to basic rights to health, education, and livelihoods. RAS end up working in the informal sector and are is often subject to abuse and exploitation.

Migration usually happens as a result of a combination of "push and pull" factors that are inter-related and often mutually dependent. Unlike migrants, RAS flee as a result of push factors such as poverty, political violence or persecution, war and human rights abuses that force them to leave their country. In addition, RAS must undergo a Refugee Status Determination (RSD) process in order to be recognised. In Malaysia, this process is organised by UNHCR.

While the UNHCR's primary objective is to protect refugees' rights and well-being, its ultimate goal is to assist in the development of durable solutions which aim to ensure safe and sustainable outcomes for refugees. Three solutions are available including voluntary repatriation (refugees who have decided to return home), local integration (when refugees are integrated into communities in their country of asylum) or resettlement to a third country (that has agreed to admit them and ultimately grant them permanent 
settlement) where it is impossible for refugees to return home or stay in the host country (UNHCR, n.d.-a). UNHCR reported about 1.1 million refugees around the world have become citizens of their asylum countries in the last decade (UNHCR, n.d.-a). Of the millions of refugees of concern to UNHCR globally, only an estimated one per cent of refugees is submitted for resettlement. The vast majority of refugees from Malaysia and Indonesia resettled in Australia, Canada, Denmark, United States, Sweden, New Zealand, and the Czech Republic and where they have family relations (JRS Asia Pacific, 2012). In Malaysia, resettlement became the primary durable solution for refugees with nearly 110,000 refugees submitted for resettlement in the United States of America (86\%), Australia (8\%), New Zealand (2\%), Canada (2\%), Norway (1\%) and Denmark (1\%) (UNHCR, n.d.-a).

\section{Refugees in Asia}

Asia has been at the forefront as a transit point for entry among refugees in the past including Bangladesh, Thailand, Malaysia and Indonesia, followed by Africa and the Middle East. Southeast Asia (SEA), has served as Asia's largest entry point with more than 1 million refugees arriving mainly from Myanmar (UNHCR, 2019a, 2021b) with Rohingyas being recognized as the most vulnerable population amongst all displaced people worldwide (Pugh, 2013; Equal Rights Trust, 2014).

Myanmar, formerly known as Burma, comprises more than 100 ethnic groups with the largest minority groups being the Shan (9\%) and Karen (7\%). Other minority ethnic groups include Mon, Karen, Rakhine, Chin, Karenni and many more that constitutes $5 \%$ or less of the population (Ekeh \& Smith, 2007). Apart from persecution conflict between these groups was largely due to ethnic and religious discrimination (Chambers, 2015a, 2015b). Karen, Karenni and Chin ethnic groups faced violent conflicts, horrific violations of human rights and oppression by the central military government (Christian Solidarity Worldwide, 2006; Ekeh \& Smith, 2007). Like many other ethnic minorities in Myanmar, the Rohingya Muslims and Chin also suffered routine discrimination especially on the status of citizenship and abuse by the government (Charney, 2005; Zarni \& Cowley, 2014; Tran, 2015). The creation of Myanmar's 1982 Citizenship Law stripped nationality status from the Rohingyas and declared them as stateless (Burma Citizenship Law, 1982), resulting in the lack of rights to medical treatment and education, exclusion from employment and other opportunities. This citizenship law only acknowledges families residing in the country before independence in 1948. The government of Myanmar continues the systematic persecution of Rohingyas, even though the elected government attempted to strengthen the human rights situation in Myanmar in 2015 (Ganguly and Miliate, 2015).

In view of humanitarian needs, proximity and similarity in faith, most Rohingyas seek refuge in Bangladesh, followed by Malaysia and Thailand (Mahmood et al., 2017; Stange et al., 2019) with many travelling to neighbouring countries via land and sea. The first forced migration of Rohingya refugees to Bangladesh was in 1978 and then in 1991-1992 (Smith, 1995). During these two periods, almost 250,000 people migrated to Bangladesh and relocated into government-led camps in Cox's Bazar in south-eastern Bangladesh (Al Imran \& Mian, 2014), currently largest refugee camp in the world. In August 2017, continued violence resulted in a mass migration of internally displaced persons (IDPs), mostly Rohingya refugees, into Bangladesh (UNHCR, 2019b) reaching a total of 884,041 by the end of March 2021 (UNHCR, 2021c).
In Thailand up to 91,479 Myanmar's refugees are housed in nine Royal Thai Government (RTG)-run "temporary shelters" along the Thai-Myanmar border, whilst 5,000 urban refugees and asylum seekers together with 550,000 stateless people from other countries reside in different areas in the country (UNHCR, 2021d). Majority of Karen and Karenni refugees left for Thailand to reside in these "temporary shelters" as early as the 1980s (Bowles, 1998). On 10 January 2017, the Thai government passed a resolution to establish a framework for screening and managing refugees and undocumented migrants (Fortify Rights, 2018), which was a positive step towards ensuring RAS have access to human rights, status, and protection. This led to the implementation of the Compulsory Migrant Health Insurance program for undocumented migrants, including refugees, to seek medical treatment in Thai public hospitals (Guinto et al., 2015). As of March 2021, refugee groups from Myanmar occupying nine camps on the Thai-Myanmar border are mainly Karen, Karenni and Burmese (UNHCR, 2021d).

Indonesia is a transit country where significant numbers of RAS reside temporarily with Australia being the intended final destination (Hugo et al., 2017). As of March 2021, there were 10,184 refugees registered with the UNHCR office in Indonesia, the majority originating from Afghanistan (56\%), followed by Somalia (10\%), Iraq (5\%) and Myanmar (5\%) (UNHCR, 2021e). As in the case of neighbouring countries, the 1951 Refugee Convention does not also apply to Indonesia, but the Indonesian government has given UNHCR the authority to provide shelter and durable solutions for these communities. A large proportion of refugees to Indonesia originate from Afghanistan, Myanmar and Somalia, and mainly live in community accommodation (UNHCR, 2016a). During the Bay of Bengal and Andaman Sea Crisis in May 2015, the Indonesian government assisted with the disembarking of 1,000 Rohingya refugees and 800 Bangladeshi migrants onto their shores and provided basic assistance, medical services, education and shelter while durable solutions were sought (UNHCR, 2016b). Under the UNHCR's mandate, RAS has access to low-cost medical treatment provided by public healthcare facilities known as 'Puskesmas' (UNHCR, 2017).

Similar to Indonesia's standing, Malaysia have been hosting refugees on humanitarian grounds. A circular in 2005 from the Attorney General's office provides a degree of immunity from prosecution for illegal entry of RAS registered with UNHCR in Malaysia (UNHCR, 2016c). However, there is no provision for access to formal education and limited access to affordable healthcare. The push factors in host countries have been key in the arrival of refugees in Malaysia.

As there is a lack of prospects of local integration in Malaysia, UNHCR-Malaysia focuses on transitional agreements to find temporary solutions, including advocacy to develop policy frameworks that would enable refugees not only to work lawfully but also to ensure access to affordable healthcare in government-run facilities and education (UNHCR, n.d.-a). The summary number of refugees from 2010 to 2020 from four transit countries in Bangladesh and Southeast Asia are presented in Table 1 (The World Bank, 2020).

Due to the ongoing global migration and refugee crisis, the medical needs of newly arrived refugees have become a pressing issue. Exposure to overcrowding, insufficient water supply, starvation, poor hygiene and sanitation, and physical and psychological stresses lead to an array of diseases (ISCG, 2018; Sultana, 2011). Thus, before being accepted for permanent resettlement, refugees must pass an overseas 
Table 1. Number of refugees from four transit countries in Bangladesh and Southeast Asia from 2010 to 2020

\begin{tabular}{lcccc}
\hline \multirow{4}{*}{ Year } & \multicolumn{4}{c}{ Host Country } \\
\cline { 2 - 5 } & Bangladesh & Thailand & Malaysia & Indonesia \\
\hline 2010 & 229,256 & 96,666 & 81,518 & 808 \\
2011 & 229,669 & 89,245 & 86,675 & 1,004 \\
2012 & 230,696 & 84,475 & 90,173 & 1,811 \\
2013 & 231,142 & 136,489 & 97,504 & 3,195 \\
2014 & 232,468 & 130,227 & 99,373 & 4,267 \\
2015 & 231,954 & 108,252 & 94,161 & 5,954 \\
2016 & 276,203 & 106,431 & 92,259 & 7,824 \\
2017 & 932,209 & 104,605 & 103,837 & 9,782 \\
2018 & 906,640 & 102,234 & 121,305 & 10,786 \\
2019 & 854,779 & 97,556 & 129,107 & 10,287 \\
2020 & 871,924 & 91,803 & 178,610 & 13,700 \\
\hline
\end{tabular}

Source: The World Bank, 2020.

medical screening review to identify conditions that might result in ineligibility for admission to that country (Chaves et al., 2009; Eckstein, 2011; Paxton et al., 2012).

\section{Refugees in Malaysia}

Malaysia lacks legal and policy mechanisms to meet the needs of RAS and stateless people in terms of protection and welfare (UNHCR, n.d.-b). Refugees recognised by the UNHCR in Malaysia have a basic "de facto" status and are not covered under national law, which classifies them as illegal or undocumented migrants (International Federation for Human Rights and SUARAM, 2008).

Malaysia's first major experience with RAS coincided with the arrival of 47 Vietnamese refugees in a boat in May 1975 (UNHCR, 2005) and subsequently, Malaysia became the temporary home for more than 250,000 Vietnam refugees as they arrived in greater numbers. The last Vietnamese refugees left Malaysia in 2005 and were repatriated voluntarily to Vietnam after spending more than 20 years in Malaysia (UNHCR, 2005). Between 1975 and the late 1980s, the Malaysian government permitted approximately 10,000 Cham from Thai refugee camps to remain and integrate into Malaysian society (Wong, 2013).

Similarly, Malaysia took the initiative to facilitate the resettlement of the Bosnian Muslims targeted by Serb nationalists for ethnic cleansing in 1992 into the country. Over 1.2 million Bosnians, including ethnic Serbs and Croats, were displaced by the war. A protection space for Bosnian refugees in Malaysia was established through the Muslim Youth Movement (ABIM) and Nair (1997) reported that Malaysia had taken in more than 300 Bosnian refugees for resettlement.

Malaysia also hosted Acehnese refugees for many years. According to Solutions for Refugees, the Malaysian government issued temporary protection documents to Acehnese refugees following the tsunami in 2005 due to the lack of a national asylum procedure and the non-signatory status of Malaysia for the 1951 Convention (UNHCR, 2007). The government regularise the situation for 30,000 Acehnese in the country by granting IMM-13 residence and work permits upon request from the Indonesian counterparts and local leaders in Aceh (United States Committee for Refugees and Immigrants, 2009). Those who were granted these documents were permitted to enter and reside in the territory for two years, the right to work and access healthcare services and access to primary education on a discretionary basis. Many Acehnese have been repatriated since then.
Table 2. Number of Myanmar refugees in Malaysia from 2010 to 2020

\begin{tabular}{lc}
\hline Year & Number of Myanmar Refugees \\
\hline 2010 & 76,120 \\
2011 & 81,150 \\
2012 & 84,670 \\
2013 & 92,290 \\
2014 & 93,870 \\
2015 & 88,640 \\
2016 & 87,040 \\
2017 & 98,040 \\
2018 & 114,230 \\
2019 & 119,230 \\
2020 & 154,030 \\
\hline
\end{tabular}

Source: Statista, 2020.

Malaysia has been a destination of choice for refugees for the past 45 years and at the end of May 2021, among the 32.75 million population of Malaysia, 2.84 million were noncitizens (Bernama, 2021) with 179,570 being RAS. Malaysia continues to host refugees from Myanmar's troubled ethnic minorities, especially the stateless Rohingya. The summary for number of Myanmar refugees in Malaysia from 2010 to 2020 are given in Table 2 (Statista, 2020). According to UNHCR (2021f), the majority of Myanmar refugees in Malaysia comprise Rohingyas $(57.3 \%)$, Chins $(12.5 \%)$ and other subethnic groups (16.4\%). The remaining 24,700 (13.8\%) originate from Pakistan, Yemen, Somalia, Syria, Afghanistan, Sri Lanka, Iraq, Palestine and other countries.

In Malaysia, there is currently no large-scale voluntary repatriation program as the political instability in Myanmar has hindered UNHCR's efforts to safely return ethnic minorities to their country of origin (UNHCR, n.d.-a). According to Wake and Cheung (2016), repatriation of Rohingya refugees without legal status in Myanmar, is unlikely to be an option in the foreseeable future. Without any legal rights to live in Myanmar, most refugees are not only unable to work but also have very limited access to quality healthcare and education (UNHCR, n.d.-b).

Refugees residing in Malaysia and camps such as Cox's Bazar in Bangladesh, may face nearly identical issues. However, the living conditions in camps, on the other hand, are far worse with; overcrowding, limited power and basic sanitation facilities. Floods, landslides, fires, and other disasters are a constant threat to the camp residents where most live in temporary shelters built with bamboo and tarpaulins, or sometimes without shelter entirely. Unlike other RAS, refugees in Malaysia are known as urban refugees because they live in urban or peri-urban area rather than a camp run by a designated authority or UNHCR. Most reside in the Klang Valley region, which comprises Kuala Lumpur and Selangor and other surrounding cities such as, Pulau Pinang and Johor with the majority living in large groups and cramped spaces in low-cost housing with proximity to the local community (Amara \& Aljunid, 2014; Nah, 2010). Refugees living in Malaysia share issues common with the urban poor such as overcrowding, violence, limited access to health, social services and education (Grabska, 2006; Horst, 2006). Nevertheless, they are fundamentally different from the urban poor and other displaced communities in the host country as they are unable to return to their home country on a long-term basis (Chatelard et al., 2009). In addition, many have experienced or witnessed abuse, torture and other 
Table 3. A summary of fees for Malaysians and foreign nationals relating to a) daily ward use, b) daily treatment and c) facility fees for foreign nationals

\begin{tabular}{rcc}
\hline Ward Class & Malaysian (USD) & Foreigners (USD) \\
\hline a) $1^{\text {st }}$ class & & \\
1 bed & 29.00 & 77.33 \\
2 bed & 21.75 & 58.00 \\
4 bed & 14.50 & 48.33 \\
$2^{\text {nd }}$ class & 9.67 & 43.50 \\
$3^{\text {rd }}$ class & 0.72 & 38.67 \\
b) $1^{\text {st }}$ class & 3.62 & 24.17 \\
$2^{\text {nd }}$ class & 1.21 & 24.17 \\
$3^{\text {rd }}$ class & Free & 24.17 \\
c) Labour room & Not stated & 72.50 \\
ICU & Not stated & 87.00 \\
NICU & Not stated & 72.50 \\
\hline
\end{tabular}

Source: Hospital Sungai Buloh (2021).

human rights violations related to conflict and displacement (Jacobsen, 2012), in addition to being officially excluded from the labour market and access to health care and education (Crisp \& Refstie, 2011).

A circular issued by the Malaysian Ministry of Health Malaysia in 2005 enabled RAS registered with UNHCR to be eligible for a $50 \%$ reduction for foreigners' treatment charges at any public healthcare facility (Equal Rights Trust, 2014; Ministry of Health Malaysia, 2014). Costs of treatment and use of health facilities for nationals and foreigners at a government hospital are given in Table 3 (Hospital Sungai Buloh, 2021) yet despite fee reduction, medical care costs remain high, especially as most refugees are daily waged, workers. The current law which prohibits RAS from formal employment compromises their ability to seek healthcare services (ISCG, 2018; Letchamanan, 2013; Yunus et al., 2021). In 2014, UNHCR launched REMEDI, a health insurance scheme for refugees, in partnership with a private insurance provider to increase access to secondary and tertiary medical services (Hamdan, 2016). However, this program faced several difficulties and was suspended due to the sharp increase in foreigners' rates at public hospitals in 2016, the voluntary nature of the scheme resulting in insufficient enrolment of refuges facilities, it was also claimed that REMEDI's medical coverage was inadequate as there was no outpatient treatment coverage (Chuah et al., 2018). Documentation concerns, fear of imprisonment, language and cultural gaps, inadequate health literacy and other barriers to accessing public health services have all been well-documented (Chuah et al., 2018). Therefore, there is now an urgent need to map Malaysia's current health care services for refugees systematically in order to inform and support future planning and programming by various non-state health authorities (Yunus et al., 2021).

Presently, refugees are also able to access free or minimal cost for medical treatment from a wide range of health care services established by non-governmental organizations (NGOs), civil society organizations (CSOs) and private entities. UNHCR supported the first primary care clinic for refugees in 2008 which was implemented by A Call to Serve, a local NGO. Tzu Chi Foundation also opened an integrated primary care clinic in 2011, partially supported by UNHCR. There was also a smaller primary care facility in Ampang, supported by the Malaysian Social Research Institute, which has discontinued in 2021 (UNHCR, n.d.-c). In 2020, the Qatar Fund for Development (QFFD) in collaboration with three medical relief NGOs such as Mercy Malaysia, Islamic Medical Association of Malaysia and Malaysian Relief to establish several private health and mobile clinics for refugees. Three of the five state clinics are in the Klang Valley. The remaining two are in Kedah and Johor. In addition, Health Equity Initiatives (HEI) is a Malaysian-based nonprofit organization, which in collaboration with several partners, provides mental health services, evidence-based advocacy, training and technical support programs, but because of budget constraints, most services are one-off or seasonal. However, many organizations are not well coordinated often resulting in replication of health programs and services (Yunus et al., 2021). Most clinics are located in urban cities such as Kuala Lumpur, Selangor, Johor and Penang where for example up to $77.1 \%$ of RAS are reported to live, whilst access to healthcare services in the other states, particularly outside city centres, is dispersed, often driven by donations and hence unsustainable (The Malaysian Reserve, 2019).

Access to health treatment is one of the major challenges for RAS and despite the apparent availability of public health facilities, the lack of legal status and protection remain key issues. Many regard themselves as outcasts in society and under constant fear and anxiety of arrest and detention. RAS also come from countries with lower standards of hygiene and sanitation and little or no knowledge of disease transmission, which raises their exposure to endemic infections such as tuberculosis, leprosy, malaria, dengue fever, hepatitis, and neglected tropical diseases including helminth and filarial infections. Based on the paper reported in 2013, a low educational background can be responsible for the perpetuation of health problems through little or lack of awareness of good health practices (Nasr et al., 2013).

\section{MATERIALS AND METHODS}

A Pubmed, MEDLINE, Microsoft Academic and Google Scholar searches were performed for both peer, non-peer-reviewed articles and reports relevant to refugees worldwide using keyword search terms refugee/health, refugee/rights, refugee / worldwide, refugee / South East Asia and refugee / Malaysia. Individual diseases such as hepatitis, parasitic infection, malaria, diphtheria, Covid -19 , and refugees from throughout the world, were also searched for in addition to citations found inside articles. We also looked at the United Nations High Commissioner for Refugees (UNHCR) official website for information on refugees around the world, as well as the World Health Organization (WHO) and the Centers for Disease Control and Prevention (CDC) for information on global health issues.

\section{RESULTS}

\section{Health concerns of Myanmar refugees}

RAS are exposed to a wide range of acute and chronic health problems including communicable and non-communicable diseases as the majority flee from countries plagued by war, violence, or economic instability (Lori \& Boyle, 2015). Thus, screening for communicable diseases plays a vital role to avoid potential infectious disease concerns in the country of asylum.

Communicable diseases are easily transmitted among large displaced populations due to congested living conditions in informal settlements, inadequate water and sanitation facilities or temporary placement sites (Lam et al., 2017). CDC has highlighted that the two most common 
diseases among Myanmar refugees include hepatitis $B$ and intestinal parasitic infections (IPI) (CDC, n.d.) in addition to four broad categories which include vaccine-preventable infections (hepatitis, measles, diphtheria, cholera and Covid19), parasitic infections, vector-borne infections (malaria and dengue), and infections spread by close contact (tuberculosis (TB), HIV and sexually-transmitted infections (STI)). As there are limited number of studies in Malaysia, this review provides an opportunity to describe the public health concerns among Myanmar refugees worldwide in order to draw policy-relevant findings that can inform local NGOs and private organizations for the design of more effective surveillance, screening, and biomonitoring systems in the management of the community.

\section{Vaccine-preventable infections}

\section{Hepatitis}

Hepatitis is a common viral disease amongst RAS in their country of origin and is characterized by liver inflammation, although there are other possible causes. There are significant benefits in reducing the burden of vaccinepreventable infectious diseases among RAS, but low vaccination coverage rates and inadequate living conditions in refugee camps often cause large-scale outbreaks (Golicha et al., 2018; Kouadio et al., 2010; Shannon et al., 2019). Viral infections of the liver are classified according to the different viruses responsible i.e., A, B, C, D and E. The most important human viruses include hepatitis $B$ virus (HBV) and hepatitis $C$ virus (HCV) which are primarily transmitted through infectious body fluids. Both varieties have been reported among Burmese refugees with infections of less than $15 \%$ (Chaves et al., 2009; CDC, n.d.; Khokon, 2017; Mazhar et al., 2021; Paxton et al., 2012). Hepatitis A and E were commonly found in refugee camps and had similar clinical presentations (Mazhar et al., 2021). A study in 2015 reported high prevalences of any previous HBV infection, as well as chronic or acute infections among Burmese refugees $(36.0 \%$ past; $9.4 \%$ chronic or acute) (Scott et al., 2015). Since chronic hepatitis B is infectious and chronically infected people can benefit from treatment, $C D C$ recommends that all refugees from countries with hepatitis B surface antigen (HBsAg; a marker of acute or chronic infection) with a prevalence rate e" $2 \%$ HBV screening or due to personal characteristics (such as injecting drug use or contact with the family of an HBVinfected person) are likely to be at risk of HBV infection (CDC, 2020; Hsan et al., 2019). According to Museru et al. (2010), prevalences of $\mathrm{HBV}$ in refugees often exceeds $10 \%$, although little data on HCV are available.

\section{Measles}

Measles is a paramyxovirus-induced, highly contagious respiratory infection (CDC, 2021) that was associated with a newly arrived refugee to the US in 2012. In addition, WHO reported a large outbreak of measles at the Rohingya refugee camp at Cox's Bazar with more than 1700 cases in late 2017 (WHO, 2017) and cases continued to rise in January 2020 with a total of 4224 cases (WHO, 2020a). Mass vaccination campaigns were conducted in response to the outbreak with $69 \%$ of children received the second dose of the measles vaccine (WHO, 2019a). Previous studies evaluated the effectiveness of this mass vaccination program and highlighted the immense success of two large scale vaccinations in preventing 77,000 new cases over the course of one year in 2017, suggesting that high vaccination coverage is essential in this population for the prevention of future outbreaks (Chin et al., 2020).

\section{Diptheriosis}

Diphtheria is another highly infectious disease that typically spreads from person to person through respiratory droplets and direct exposure to exudates of the lesion, but transmission can be prevented through vaccination using diphtheria antitoxin (DAT) and/or antibiotics (Mondiale \& WHO, 2017). In 2017, an outbreak of diphtheria occurred in Bangladesh, shortly after 700,000 Rohingya migrants poured into the refugee camp in Cox's Bazar (Chan et al., 2018) with the initial index case reported in November 2017 in the Balukhali camp (Finger et al., 2019). To date, the total number of reported cases of diphtheria is 9,266 (3016 in 2017; 5330 in 2018; 614 in 2019; 226 in 2020, and 80 as of May 2021) with 9023 were reported from the camps and 243 from the host community (WHO, 2021a). A total of 47 diphtheria patients have died from the beginning of the epidemic until the end of May 2021 (case fatality rate <1\%) (WHO, 2021a). After three rounds of mass vaccination in children only slightly reduced transmission, and further public health measures are needed to end the epidemic (Polonsky et al., 2021). The series of acute outbreaks of both measles and diphtheria challenged the ability of healthcare providers to control infections in refugees (White, 2017).

\section{Cholera}

Cholera is fatal if untreated and more often amplified in crowded refugee camps due to inadequate sanitation and limited access to clean water in camps. Several cholera outbreaks also took place in the Mae La refugee camp involving Karen refugees in 2005 with more than 1000 cases and the most recent in 2010 with more than 350 cultureconfirmed cases including the death of a pregnant woman. In January 2013, a campaign was launched to vaccinate Mae La refugees and within 8 months after the inception of the campaign, no additional cholera cases have occurred (AsiaNews, 2010; Phares \& Ortega, 2014).

Considering the imminent threat of infectious disease outbreaks due to the influx of forcibly Displaced Myanmar Nationals into Bangladesh, the Government of Bangladesh with WHO launched a vaccination program for all except $<1$ yer old children against three deadly diseases (measles, rubella and poliomyelitis) and oral cholera (Khan et al., 2019). The world's second-largest oral cholera vaccination campaign was launched in October 2017 by the United Nations Children's Fund (UNICEF) and World Health Organization (WHO), with 900,000 doses administered during mass vaccination campaigns in two sub-districts of Cox's Bazar in Ukhiya and Teknaf in Bangladesh (UNICEF, 2017).

\section{Coronaviruses}

More recently UNHCR reported that globally 21,000 of the world's 30 million refugees have been tested positive for the COVID-19 virus across 97 countries with Cox's Bazar district also testing positive for COVID-19 (WHO, 2021a), except that only $1 \%(15,175$ tests $)$ of the population has been tested (WHO, 2020b). As of May 2021, a total of 670 COVID-19 cases were reported in the Rohingya refugee camps. Since the outbreak 11 people in the camp have died of confirmed COVID-19, with a case fatality rate of $1.6 \%$ (WHO, 2021a). According to Berkley (2020), low and middle-income countries will receive equal access and coverage to the COVID-19 vaccination, as well as $5 \%$ of total available vaccine doses for RAS. This has been agreed by the COVAX global vaccine centre to ensure that these communities are not left behind. Extensive communication between community members and religious leaders is ongoing in all camps in order to increase the Rohingya refugee confidence and acceptance by COVID- 
19 vaccination (WHO, 2021a). In Malaysia, as reported by Reuters (2021) all non-citizens including students, RAS registered with UNHCR and undocumented migrants will be eligible for a free COVID-19 vaccine. According to the Malaysian government, vaccinating the most vulnerable during a pandemic is considered a humanitarian act.

\section{Parasitic infections}

Intestinal parasitic infections (IPIS), caused by soiltransmitted helminths (STHs) and protozoan parasites, are among the most prevalent infections in humans in low developing countries where sanitation and hygiene are poor. Lozano et al. (2012) stated that the infectious protozoan parasites pose a major health threat and cause more than a million deaths per year. Neglected tropical diseases such as STHs, filariasis, food and water-borne cryptosporidiosis, amoebiasis and giardiasis are highly prevalent in marginalized communities. Mild infections are generally asymptomatic but heavy infections can lead to clinical consequences. Some studies have demonstrated that severe ascariasis, trichuriasis and hookworm infections are indicators of malnutrition, iron deficiency anaemia, and low serum retinol, indicative of vitamin A deficiency (Al-Mekhlafi et al., 2005; Ngui et al., 2012).

Among Burmese refugees, Ascaris lumbricoides, Trichuris trichiura, hookworm and Giardia sp. are some of the typical parasite infections in tropical populations (CDC, n.d.). STHs are prevalent amongst the poorest and most deprived communities and the global strategy to control these infections is dependent upon a large-scale administration of anthelminthic drugs to high-risk groups. However, reinfection is known to occur post-treatment particularly in the case of $A$. lumbricoides and $T$. trichiura even as early as 3 months reaching pre-treatment levels after 12 months (Jia et al., 2012). This has created an obstacle for WHO to attain the elimination global target for soil-transmitted helminthiasis by 2030. Previous reports have highlighted STHs among Burmese children and Karen's students with infections as high as 69\% (Montresor et al., 2004; Saksirisampant et al., 2004) with A. lumbricoides and T. trichiura. In addition, schistosomiasis, strongyloidiasis, hookworm, taeniasis and IPIs is widely reported among RAS from Myanmar (Brummaier et al., 2021; Chaves et al., 2009; CDC, n.d.; McCleery et al., 2015; O'Connell et al., 2018; Paxton et al., 2012; Piangjai et al., 2003).

Similar studies in Malaysia are limited. However, a recent study in the Klang Valley among refugee children showed approximately more than a third were infected with STH (Alaribi et al., 2020).

\section{Vector-borne infections (Mosquito associated infections)}

With approximately 228 million cases worldwide and 405,000 deaths annually in 2018, malaria remains a major public health issue (WHO, 2020c). The WHO reported Myanmar as a malaria-endemic nation with $60 \%$ of the population at risk of transmission (Department of Public Health, Ministry of Health and Sports, The Republic of The Union of Myanmar, 2015) with outbreaks of mosquito-borne infections such as malaria and dengue frequently corresponding with the monsoon season (WHO, 2018a). Malaria is highly seasonal in 13 districts located in the southeast and northeast regions of the country (Haque et al., 2014). However previous studies showed a low presence of malaria infections among Myanmar refugees in their settlements (Chaves et al., 2009; Lu et al., 2020; Paxton et al., 2012).

Dengue is another common mosquito-borne disease in the tropics caused by the dengue virus (DENV) which spread rapidly mostly in urban and suburban areas. In the past two decades, WHO reported the number of dengue fever cases had risen over eightfold, from 505,430 in 2000 to 2.4 million in 2010 and 5.2 million in 2019 (WHO, 2021b). Rare outbreaks of dengue haemorrhagic fever occurred in 1987 in a longterm Cambodian refugee camp near the Thai-Cambodian border (Elias et al., 1990) together with a Burmese refugee camp at the Thai border (AsiaNews, 2010) and also in the Cox's Bazar district involving Rohingya refugees (WHO, 2019b).

\section{Infections spread by close contact}

Tuberculosis is classified into either a latent /non-infectious type or an active infection which can spread to other members of the community (CDC, 2011). Crowded conditions, malnutrition and poor quality of life normally observed in refugee camps are responsible for the spread of this disease. Myanmar is ranked as one of the top 30 countries with the highest levels of tuberculosis infections (Kanabus, 2021; WHO, $2020 d$ ). Several studies have shown high prevalences of latent infections in Myanmar and Rohingya refugees (Chaves et al., 2009; Jasmine et al., 2018; Wong \& Lee, 2020), whereas levels of active infections were mainly low (Chaves et al., 2009; Jasmine et al., 2018).

Records on sexually transmitted infections (STI) such as chlamydia, gonorrhoea and HIV among Myanmar refugees were limited. Unpublished data from Minnesota and Texas (CDC, n.d.) stated that this infection is not common among Myanmar refugees with low infections of less than 2\% being recorded (Chaves et al., 2009). However, the prevalence of STI in this population is extremely concerning especially as Myanmar has the second-highest HIV/AIDS rate in South East Asia at $0.8 \%$ (WHO, 2018b) which is exacerbated by inadequate health services (UNHCR, 2019c). While CDC highlighted hepatitis $B$ and IPIs are some of the health concerns especially among Myanmar refugees (CDC, n.d.).

The health concerns of refugees in Malaysia are not well captured. A UNHCR survey in 2015 highlighted almost a quarter suffer from non-communicable diseases such as diabetes, cardiovascular disease and hypertension among adult refugees (UNHCR, 2015). While $27.5 \%$ of children are underweight and $11.5 \%$ stunted. These numbers are likely conservative estimates and other existing health issues have not been adequately recorded. The majority of RAS live among local populations in cities with hygiene and overcrowding being major concerns. All of these can increase the risk of infections such as dengue fever which is endemic in this country with the increased risk, particularly in urban and peri-urban areas. This is followed by hand, foot and mouth disease, leptospirosis, hepatitis B and HIV), and more recently is SARs CoV-2 that has plagued the world is at risk of infection. STHs is also considered endemic, with infections vary greatly across the population particularly children among underprivileged communities (Al-Mekhlafi et al., 2005). Fundamental problems according to Chuah et al. (2018) are; poor health literacy, lack of awareness of one's entitlement to healthcare, language barrier, cultural disparities and inability to afford healthcare owing to inadequate livelihoods.

Despite the dramatic increase numbers of refugees to Malaysia over the last decade, there is still lack of information as there has yet a comprehensive study to examine the public health status of refugees in Malaysia. Without a concerted effort to address the social, cultural and economic determinants of health, as well as more inclusive health policies this community will continue to suffer. Therefore, further studies are necessary in order to address their health concerns and shape an effective public health policy. 


\section{CONCLUSIONS}

RAS is often subjected to a variety of health risks whether in the country of origin, during transit and destination or on their return. The key determinant of health for the population is the presence of legislative and administrative frameworks to effectively manage RAS in the country without which the population has no formal access to basic education, health services and work rights. A comprehensive study on the health status among the largest RAS community in the region is urgently required to bridge the gap of information on disease prevalences in the community not only to improve their health status but also to identify potential public health risks they are vulnerable to and to the community at large.

Despite adequate healthcare is provided for RAS in most countries in Southeast Asia, the majority face many challenges including the provision and cost of treatment, inadequate knowledge of diseases, language barriers, fears of deportation and also arrest. The incidences of vaccinepreventable infections (hepatitis, measles, diphtheria, cholera and Covid-19), parasitic infections, vector-borne infections (malaria and dengue), infections spread by close contact (tuberculosis (TB), HIV and sexually transmitted infections (STI) continue to influence the health and wellbeing of RAS globally and in Malaysia. Some issues that need to be addressed by stakeholders are the inclusion of RAS in national vaccination programmes in addition to introducing health programs at preventive levels and increasing an understanding of disease and transmission through good practices. In addition, improvements in health access coverage should be undertaken especially in communities that do not reside in high-density locations.

The Sustainable Development Goals (SDGs) was established to reduce the gap between urban populations by 2030 , especially immigrants, refugees and vulnerable groups.

A comprehensive strategy for universal health coverage is therefore required to provide healthcare for all noncitizens in the country, including migrants, stateless and refugee communities, which will improve their health status and address public health concerns that affect all populations in the country.

\section{ACKNOWLEDGEMENTS}

The authors would like to thank to everyone who contributed to this article directly and indirectly.

\section{Conflict of interest}

None of the authors have any conflicts of interest to declare.

\section{Funding}

This work was supported by Impact Oriented Interdisciplinary Research Grant (IIRG) under Grant [IIRG002A-2020SAH] and Higher Institution Centre of Excellence (HICoE) Program (Vector-Rodents) under Grant [MO002-2019].

\section{REFERENCES}

Al Imran, H.F. \& Mian, N. (2014). The Rohingya refugees in Bangladesh: A vulnerable group in law and policy. Journal of Studies in Social Sciences 8: 226-253.
Al-Mekhlafi, H.M., Azlin, M., Nor Aini, U., Shaik, A., Sa'iah, A., Fatmah, M.S., Ismail, M.G., Ahmad, F., Aisah M.Y., Rozlida, A.R. et al. (2005). Protein-energy malnutrition and soiltransmitted helminthiases among Orang Asli children in Selangor, Malaysia. Asia Pacific Journal of Clinical Nutrition 14: 188-194.

Alaribi, F.I., Unyah, N.Z., Misni, N., Masri, S.N. \& Osman, M. (2020). The Prevalence of Soil-Transmitted Helminths Infection and Its Association with Anaemia Among Refugee School Children in The Klang Valley, Malaysia. Malaysian Journal of Medicine and Health Sciences 16: 46-53.

Amara, A.H. \& Aljunid, S.M. (2014). Noncommunicable diseases among urban refugees and asylum-seekers in developing countries: a neglected health care need. Globalization and Health 10: 1-14. https://doi.org/10.1186/ 1744-8603-10-24

AsiaNews. (2010). Dengue and Cholera Hit a Burmese Refugee Camp on The Border Between Thailand and Myanmar. AsiaNews. http://www.asianews.it/news-en/Dengue-andcholera-hit-a-Burmese-refugee-camp-on-the-borderbetween-Thailand-and-Myanmar-18917.html. Accessed 2 February 2021.

Berkley, S. (2020). COVAX Explained. Gavi, the Vaccine Alliance. https://www.gavi.org/vaccineswork/covax-explained. Accessed 25 May 2021.

Bernama. (2021). Malaysia's Population Stands at 32.75 million. New Straits Times Online. https://www.nst.com. $\mathrm{my} /$ news/nation/2021/05/693513/malaysias-populationstands-3275-million. Accessed 10 July 2021.

Bowles, E. (1998). From village to camp: refugee camp life in transition on the Thailand-Burma border. Forced Migration Review 2: 11-14.

Brummaier, T., Tun, N.W., Min, A.M., Gilder, M.E., Archasuksan, L., Proux, S., Kiestra, D., Charunwatthana, P., Utzinger, J., Paris, D.H. et al. (2021). Burden of soil-transmitted helminth infection in pregnant refugees and migrants on the Thailand-Myanmar border: Results from a retrospective cohort. PLoS Neglected Tropical Diseases 15: e0009219. https://doi.org/10.1371/journal.pntd.0009219

Burma Citizenship Law. (1982). Refworld.https://www. refworld.org/docid/3ae6b4f71b.html. Accessed 2 March 2021.

Centers for Disease Control and Prevention (CDC). (n.d.). Immigrant, Refugee, and Migrant Health: Burmese Refugee Health Profile. https://www.cdc.gov/immigrant refugeehealth/profiles/burmese/priority-healthconditions/index.html. Accessed 19 February 2021.

Centers for Disease Control and Prevention (CDC). (2011). TB Elimination: The Difference Between Latent TB Infection and TB Disease. https://www.cdc.gov/tb/publications/ factsheets/general/LTBlandActiveTB.pdf. Accessed 20 February 2021.

Centers for Disease Control and Prevention (CDC). (2020). Clinical Presentations and Domestic Diagnostic Testing for Specific Viral Hepatitides. https://www.cdc.gov/ immigrantrefugeehealth/guidelines/domestic/ hepatitis-screening-guidelines.html. Accessed 20 February 2021.

Centers for Disease Control and Prevention (CDC). (2021). Epidemiology of Vaccine Preventable Diseases Centers for Disease Control and Prevention: Pinkbook, Measles. https://www.cdc.gov/vaccines/pubs/pinkbook/ meas.html\#virus. Accessed 20 February 2021. 
Chambers, P. (2015a). The Rohingyas' trail of tears: Continuing persecution of an ethnic minority in Myanmar. South Asia Democratic Forum (SADF). https://www.sadf.eu/sadffocus-nr-9-the-rohingyas-trail-of-tears-continuingpersecution-of-an-ethnic-minority-in-myanmar/. Accessed 15 May 2021.

Chambers, P. (2015b). Thailand must end its own Rohingya atrocity. The Diplomat. https://thediplomat.com/2015/10/ thailand-must-end-its-own-rohingya-atrocity/. Accessed 21 May 2021.

Chan, E.Y.Y., Chiu, C.P. \& Chan, G.K. (2018). Medical and health risks associated with communicable diseases of Rohingya refugees in Bangladesh 2017. International Journal of Infectious Diseases 68: 39-43. https://doi.org/10.1016/ j.ijid.2018.01.001

Charney, M.W. (2005). Theories and Historiography of the Religious Basis of Ethnonyms in Rakhaing (Arakan), Myanmar (Burma). In: Workshop 'The Forgotten Kingdom of Arakan: A Public Seminar on the People of Present Day Arakan State of Myanmar', Bangkok, Thailand.

Chatelard, G., El-Abed, O. \& Washington, K. (2009). Dissertation: Protection, mobility and livelihood challenges of displaced Iraqis in urban settings in Jordan. International Catholic Migration Commission.

Chaves, N.J., Gibney, K.B., Leder, K., O’brien, D.P., Marshall, C. \& Biggs, B.A. (2009). Screening practices for infectious diseases among Burmese refugees in Australia. Emerging Infectious Diseases 15: 1769-1772. https://doi.org/10.3201/ eid1511.090777

Chin, T., Buckee, C.O. \& Mahmud, A.S. (2020). Quantifying the success of measles vaccination campaigns in the Rohingya refugee camps. Epidemics 30: 100385. https:// doi.org/10.1016/j.epidem.2020.100385

Christian Solidarity Worldwide. (2006). FACT-FINDING REPORT MARCH 2006 BURMESE CHIN REFUGEES IN MALAYSIA. https:/ /www.chinhumanrights.org/wp-content/uploads/2009/07/ Burmese_Chin_Refugee_in_Malaysia.pdf. Accessed 15 May 2021.

Chuah, F.L.H., Tan, S.T., Yeo, J. \& Legido-Quigley, H. (2018). The health needs and access barriers among refugees and asylum-seekers in Malaysia: a qualitative study. International Journal for Equity in Health 17: 1-15. https://doi.org/ 10.1186/s12939-018-0833-x

Crisp, J. \& Refstie, H. (2011). The Urbanisation of Displaced People. Cities Alliance. https://www.citiesalliance.org/ resources/publications/cities-alliance-knowledge/ urbanisation-displaced-people. Accessed 13 May 2021.

Department of Public Health, Ministry of Health and Sports, The Republic of The Union of Myanmar. (2015). National strategic Plan: Intensifying malaria control and accelerating progress towards malaria elimination (20162020).

Eckstein, B. (2011). Primary care for refugees. American Family Physician 83: 429-436.

Ekeh, C. \& Smith, M. (2007). Minorities in Burma. Minority Rights Group International 30: 1-5.

Elias, C.J., Alexander, B.H. \& Sokly, T. (1990). Infectious disease control in a long-term refugee camp: the role of epidemiologic surveillance and investigation. American Journal of Public Health 80: 824-828. https://doi.org/10.2105/ AJPH.80.7.824

Equal Rights Trust. (2014). Equal Only in Name: The Human Rights of Stateless Rohingya in Malaysia. Refworld. https://www.refworld.org/docid/5444d3024.html. Accessed 13 May 2021.
Finger, F., Funk, S., White, K., Siddiqui, M.R., Edmunds, W.J. \& Kucharski, A.J. (2019). Real-time analysis of the diphtheria outbreak in forcibly displaced Myanmar nationals in Bangladesh. BMC Medicine 17: 1-11. https://doi.org/ 10.1186/s12916-019-1288-7

Fortify Rights. (2018). Thailand: End raids and arbitrary detention of refugees. Fortify Rights. https://www. fortifyrights.org/tha-inv-2018-10-12/. Accessed 13 May 2021.

Ganguly, S. \& Miliate, B. (2015). Refugees and neighbors: Rohingya in Bangladesh. The Diplomat. https://thediplomat. com/2015/10/refugees-and-neighbors-rohingya-inbangladesh/. Accessed 2 March 2021.

Golicha, Q., Shetty, S., Nasiblov, O., Hussein, A., Wainaina, E., Obonyo, M., Macharia, D., Musyoka, R.N., Abdille, H., Ope, M. et al. (2018). Cholera Outbreak in Dadaab Refugee Camp, Kenya - November 2015-June 2016. Morbidity and Mortality Weekly Report 67: 958-961. https://doi.org/10. 15585/mmwr.mm6734a4

Grabska, K. (2006). Marginalization in urban spaces of the global south: Urban refugees in Cairo. Journal of Refugee Studies 19: 287-307. https://doi.org/10.1093/jrs/fel014

Guinto, R.L.L.R., Curran, U.Z., Suphanchaimat, R. \& Pocock, N.S. (2015). Universal health coverage in 'One ASEAN': are migrants included? Global Health Action 8: 25749. https:// doi.org/10.3402/gha.v8.25749

Hamdan, N. (2016). Policy to address medical issues faced by migrants in Malaysia, says UNHCR rep. The Star. https:// www.thestar.com.my/news/nation/2016/06/08/insurancefor-refugees-launched-policy-to-address-medicalissues-faced-by-migrants-in-malaysia-says/. Accessed 15 May 2021.

Haque, U., Overgaard, H.J., Clements, A.C., Norris, D.E., Islam, N., Karim, J., Roy, S., Haque, W., Kabir, M., Smith, D.L. et al. (2014). Malaria burden and control in Bangladesh and prospects for elimination: an epidemiological and economic assessment. The Lancet Global Health 2: e98-e105. https://doi.org/10.1016/S2214-109X(13)70176-1

Horst, C. (2006). Introduction: refugee livelihoods: continuity and transformations. Refugee Survey Quarterly 25: 6-22.

Hospital Sungai Buloh. (2021). Caj dan Bayaran. https:// hsgbuloh.moh.gov.my/en/corporate/contact-us/hospitalinformation/15-pelawat/caj-dan-bayaran.html. Accessed 15 May 2021.

Hsan, K., Griffiths, M.D., Gozal, D. \& Rahman, M.A. (2019). HIV infection in Rohingya refugees in Bangladesh. The Lancet HIV 6: e419. https://doi.org/10.1016/S2352-3018(19) 30156-0

Hugo, G., Tan, G. \& Napitupulu, C.J. (2017). Indonesia as a transit country in irregular migration to Australia. In: A long way to go: Irregular migration patterns, processes, drivers and decision-making, Mcauliffe, M. \& Koser, K. (editors). Australia: Australian National University Press, pp. 167-191.

International Federation for Human Rights and SUARAM. (2008). Undocumented migrants and refugees in Malaysia: Raids, detention and discrimination. https:// www.fidh.org/en/region/asia/malaysia/Undocumentedmigrants-and-refugees. Accessed 15 May 2021.

Inter Sector Coordination Group (ISCG). (2018). Situation report: Rohingya refugee crisis, Cox's Bazar. Reliefweb. https://reliefweb.int/report/bangladesh/iscg-situationreport-rohingya-refugee-crisis-cox-s-bazar-21-june-2018. Accessed 2 February 2021. 
Jacobsen, K. (2012). The economic security of refugees: Social capital, remittances, and humanitarian assistance. In: Global migration, Khory, K.R. (editor). New York: Palgrave Macmillan, pp. 65-85. https://doi.org/10.1057/978113 7007124_4

Jasmine, R., Khan, A.A., Kamal, A.K.M., Karim, A.R. \& Haque, M.M. (2018). Prevalence of Pulmonary Tuberculosis among Rohingya Refugees in Kutupalong Camp, Bangladesh. Journal of Armed Forces Medical College, Bangladesh 14: 197199. https://doi.org/10.3329/jafmc.v14i2.45909

Jia, T.W., Melville, S., Utzinger, J., King, C.H. \& Zhou, X.N. (2012). Soil-transmitted helminth reinfection after drug treatment: A systematic review and meta-analysis. PLOS Neglected Tropical Diseases 6: e1621. https://doi.org/ 10.1371/journal.pntd.0001621

JRS Asia Pacific. (2012). The Search: Protection Space in Malaysia, Thailand, Indonesia, Cambodia and the Philippines. JRS Asia Pacific. https://www.refworld.org/ pdfid/506bfb622.pdf. Accessed 15 May 2021.

Kanabus, A. (2021). High burden TB countries - 2021 update. TBFACTS.ORG. https://tbfacts.org/high-burden-tb/. Accessed 20 February 2021.

Khan, A.I., Islam, M.T., Siddique, S.A., Ahmed, S., Sheikh, N., Siddik, A.U., Islam, M.S. \& Qadri, F. (2019). Post-vaccination campaign coverage evaluation of oral cholera vaccine, oral polio vaccine and measles-rubella vaccine among Forcibly Displaced Myanmar Nationals in Bangladesh. Human Vaccines \& Immunotherapeutics 15: 2882-2886. https:/ /doi.org/10.1080/21645515.2019.1616502

Khokon, S.H. (2017). Pregnant Rohingya women face high risk of Hepatitis C: Report. India Today. https://www. indiatoday.in/world/story/pregnant-rohingya-womenface-high-risk-hepatitis-c-b-1071050-2017-10-28. Accessed 1 July 2021.

Kouadio, I.K., Kamigaki, T. \& Oshitani, H. (2010). Measles outbreaks in displaced populations: a review of transmission, morbidity and mortality associated factors. BMC International Health and Human Rights 10: 1-10. https:// doi.org/10.1186/1472-698X-10-5

Lam, E., Al-Tamimi, W., Russell, S.P., Butt, M.O.U.I., Blanton, C., Musani, A.S. \& Date, K. (2017). Oral cholera vaccine coverage during an outbreak and humanitarian crisis, Iraq, 2015. Emerging Infectious Diseases 23: 38-45. https:// doi.org/10.3201/eid2301.160881

Letchamanan, H. (2013). Myanmar's Rohingya refugees in Malaysia: Education and the way forward. Journal of International and Comparative Education (JICE) 2: 86-97. https://doi.org/10.14425/00.50.24

Lori, J.R. \& Boyle, J.S. (2015). Forced migration: Health and human rights issues among refugee populations. Nursing Outlook 63: 68-76. https://doi.org/10.1016/j.outlook.2014. 10.008

Lozano, R., Naghavi, M., Foreman, K., Lim, S., Shibuya, K., Aboyans, V., Abraham, J., Adair, T., Aggarwal, R., Ahn, S.Y. et al. (2012). Global and regional mortality from 235 causes of death for 20 age groups in 1990 and 2010: a systematic analysis for the Global Burden of Disease Study 2010. The Lancet 380: 2095-2128. https://doi.org/10.1016/S01406736(12)61728-0

Lu, A., Cote, O., Dimitrova, S.D., Cooley, G., Alamgir, A., Uzzaman, M.S., Flora, M.S., Widiati, Y., Akhtar, M.S., Vandenent, M. et al. (2020). Screening for malaria antigen and anti-malarial IgG antibody in forcibly-displaced Myanmar nationals: Cox's Bazar district, Bangladesh, 2018. Malaria Journal 19: 1-8. https://doi.org/10.1186/s12936-020-03199-4
Mahmood, S.S., Wroe, E., Fuller, A. \& Leaning, J. (2017). The Rohingya people of Myanmar: health, human rights, and identity. The Lancet 389: 1841-1850. https://doi.org/10.1016/ S0140-6736(16)00646-2

Mazhar, M.K.A., Finger, F., Evers, E.S., Kuehne, A., Ivey, M., Yesurajan, F., Shirin, T., Ajim, N., Kabir, A., Musto, J. et al. (2021). An outbreak of acute jaundice syndrome (AJS) among the Rohingya refugees in Cox's Bazar, Bangladesh: Findings from enhanced epidemiological surveillance. PloS One 16: e0250505. https://doi.org/10.1371/journal. pone. 0250505

McCleery, E.J., Patchanee, P., Pongsopawijit, P., Chailangkarn, S., Tiwananthagorn, S., Jongchansittoe, P., Dantrakool, A., Morakote, N., Phyu, H., Wilkins, P.P. et al. (2015). Taeniasis among refugees living on Thailand-Myanmar border, 2012. Emerging Infectious Diseases 21: 1824-1826. https:// doi.org/10.3201/eid2110.141657

Ministry of Health Malaysia (MOH). (2014). Garis Panduan Pelaksanaan Perintah Fi (Perubatan) (Kos Perkhidmatan) 2014. https://www.moh.gov.my/index.php/database_ stores/store_view_page/31/257. Accessed 15 July 2021.

mondiale de la Santé, O. \& World Health Organization. (2017). Diphtheria vaccine: WHO position paper-August 2017Vaccin antidiphtérique: Note de synthèse de I'OMS-août 2017. Weekly Epidemiological Record= Relevé épidémiologique hebdomadaire 92: 417-435.

Montresor, A., Zin, T.T., Padmasiri, E., Allen, H. \& Savioli, L. (2004). Soil transmitted helminthiasis in Myanmar and approximate costs for countrywide control. Tropical Medicine \& International Health 9: 1012-1015. https://doi.org/ 10.1111/j.1365-3156.2004.01297.x

Museru, O.I., Vargas, M., Kinyua, M., Alexander, K.T., FrancoParedes, C. \& Oladele, A. (2010). Hepatitis B virus infection among refugees resettled in the US: High prevalence and challenges in access to health care. Journal of Immigrant and Minority Health 12: 823-827. https://doi.org/10.1007/ s10903-010-9335-7

Nah, A.M. (2010). Refugees and space in urban areas in Malaysia. Forced Migration Review 34: 29-31.

Nair, S. (1997). Islam in Malaysian foreign policy. London: Routledge. https://doi.org/10.4324/9780203425381

Nasr, N.A., Al-Mekhlafi, H.M., Ahmed, A., Roslan, M.A. \& Bulgiba, A. (2013). Towards an effective control programme of soil-transmitted helminth infections among Orang Asli in rural Malaysia. Part 2: Knowledge, attitude, and practices. Parasites \& Vectors 6: 1-12. https://doi.org/ 10.1186/1756-3305-6-28

Ngui, R., Lim, Y.A.L., Chong Kin, L., Sek Chuen, C. \& Jaffar, S. (2012). Association between anaemia, iron deficiency anaemia, neglected parasitic infections and socioeconomic factors in rural children of West Malaysia. PLOS Neglected Tropical Diseases 6: e1550. https://doi.org/ 10.1371/journal.pntd.0001550

O'Connell, E.M., Mitchell, T., Papaiakovou, M., Pilotte, N., Lee, D., Weinberg, M., Sakulrak, P., Tongsukh, D., OduroBoateng, G., Harrison, S. et al. (2018). Ancylostoma ceylanicum hookworm in Myanmar refugees, Thailand, 2012-2015. Emerging Infectious Diseases 24: 1472-1481. https://doi.org/10.3201/eid2408.180280

Paxton, G.A., Sangster, K.J., Maxwell, E.L., McBride, C.R.J. \& Drewe, R.H. (2012). Post-arrival health screening in Karen refugees in Australia. PIOS ONE 7: e38194. https://doi.org/ 10.1371/journal.pone.0038194 
Phares, C.R. \& Ortega, L. (2014). Refugee health and cholera. Clinical Infectious Diseases: An Official Publication of the Infectious Diseases Society of America 58: iv-v. https://doi.org/ $10.1093 / \mathrm{cid} / \mathrm{cit} 762$

Piangjai, S., Sukontason, K. \& Sukontason, K.L. (2003). Intestinal parasitic infections in hill-tribe schoolchildren in Chiang Mai, northern Thailand. Southeast Asian Journal of Tropical Medicine and Public Health 34: 90-93.

Polonsky, J.A., Ivey, M., Mazhar, M.K.A., Rahman, Z., le Polain de Waroux, O., Karo, B., Jalava, K., Vong, S., Baidjoe, A., Diaz, J. et al. (2021). Epidemiological, clinical, and public health response characteristics of a large outbreak of diphtheria among the Rohingya population in Cox's Bazar, Bangladesh, 2017 to 2019: A retrospective study. PLoS Medicine 18: e1003587. https://doi.org/10.1371/journal. pmed.1003587

Pugh, C. (2013). Is Citizenship the answer? Constructions of belonging and exclusion for the stateless Rohingya of Burma. International Migration Institute. https://ora.ox. ac.uk/objects/uuid:4cf79487-7826-442c-826d684b41c3ea28. Accessed 15 May 2021.

Reuters. (2021). Malaysia Offers COVID-19 vaccinations to undocumented migrants. Thomson Reuters Foundation News. https://news.trust.org/item/20210211035604-cal3u/ . Accessed 25 May 2021.

Saksirisampant, W., Prownebon, J., Kanmarnee, P., Thaisom, S., Yenthakam, S. \& Nuchprayoon, S. (2004). Prevalence of Parasitism Among Students of The Karen Hill-Tribein Mae Chame District, Chiang Mai Province, Thailand. Journal of The Medical Associatioin of Thailand 87: S278-S283.

Scott, K.C., Taylor, E.M., Mamo, B., Herr, N.D., Cronkright, P.J., Yun, K., Altshuler, M. \& Shetty, S. (2015). Hepatitis B screening and prevalence among resettled refugeesUnited States, 2006-2011. MMWR. Morbidity and Mortality Weekly Report 64: 570-573.

Shannon, K., Hast, M., Azman, A.S., Legros, D., McKay, H. \& Lessler, J. (2019). Cholera prevention and control in refugee settings: Successes and continued challenges. PLOS Neglected Tropical Diseases 13: e0007347. https://doi.org/ 10.1371/journal.pntd.0007347

Smith, M. (1995). The Muslim Rohingya of Burma. Draft for Consultation at Conference of Burma Centrum Nederland.

Stange, G., Kourek, M., Sakdapolrak, P. \& Sasiwongsaroj, K. (2019). Forced Migration in Southeast Asia. ASEAS-Austrian Journal of South-East Asian Studies 12: 249-265. https:// doi.org/10.14764/10.ASEAS-0024

Statista. (2020). Number of Refugees and Asylum-Seekers from Myanmar in Malaysia 2010-2019. https://www. statista.com/statistics/955387/myanmar-refugeesasylum-seekers-in-malaysia/. Accessed 23 February 2021.

Sultana, N. (2011). Health Care at Rohingya Refugee Camp A Case Study on RTM Initiative. ACCESS Health International, RTM International. https://healthmarketinnovations.org/ sites/default/files/Healthcare_Refugee_Camp.pdf. Accessed 2 February 2021.

The Malaysian Reserve. (2019). QFFD humanitarian clinic for refugees in Malaysia. The Malaysian Reserve. https:// themalaysianreserve.com/2019/12/23/qffd-humanitarianclinic-for-refugees-in-malaysia/. Accessed 24 May 2021.

The World Bank. (2020). Refugee population by country or territory of asylum. https://data.worldbank.org/indicator/ SM.POP.REFG end $=2019 \&$ start $=2000$. Accessed 23 February 2021.

Tran, C. (2015). South-East Asian migrant crisis: Who are the Rohingya fleeing Myanmar by Boat? ABC News. http:// www.abc.net.au/news/2015-05-21/explainer-whoare-therohingya-fleeing-myanmar/6487130. Accessed 2 May 2021.
United Nations High Commissioner for Refugees (UNHCR). (n.d.-a). Durable Solutions in Malaysia. https://www. unhcr.org/durable-solutions-in-malaysia.html. Accessed 15 May 2021.

United Nations High Commissioner for Refugees (UNHCR). (n.d.-b). A Vision for Change. https://www.unhcr.org/enmy/a-vision-for-change.html. Accessed 15 May 2021.

United Nations High Commissioner for Refugees (UNHCR). (n.d.-c). Public Health in Malaysia. https://www.unhcr.org/ en-my/public-health-in-malaysia.html. Accessed 20 August 2021.

United Nations High Commissioner for Refugees (UNHCR). (2005). Last Vietnamese boat refugee leaves Malaysia. https://www.unhcr.org/en-my/news/latest/2005/8/ 43141 e $9 \mathrm{~d} 4 /$ vietnamese-boat-refugee-leaves malaysia.html. Accessed 2 February 2021.

United Nations High Commissioner for Refugees (UNHCR). (2007). Chapter 7, Solutions for Refugees. In: The 10-Point Plan in Action. https://www.unhcr.org/50a4c17f9.pdf. Accessed 16 May 2021.

United Nations High Commissioner for Refugees (UNHCR). (2010). Convention and protocol relating to the status of refugees. https://www.unhcr.org/en-my/3b66c2aa10. Accessed 2 May 2021.

United Nations High Commissioner for Refugees (UNHCR). (2015). At A Glance: Health Access and Utilization Survey Among Non-Camp Refugees in Malaysia.

United Nations High Commissioner for Refugees (UNHCR). (2016a). Indonesia Factsheet December 2016. https:// www.unhcr.org/id/wp-content/uploads/sites/42/2017/05/ Indonesia-Fact-Sheet-December-2016.pdf. Accessed 10 May 2021.

United Nations High Commissioner for Refugees (UNHCR). (2016b). Submission by the United Nations High Commissioner for Refugees for the Office of the High Commissioner for Human Rights' Compilation Report Universal Periodic Review: 3rd Cycle, 27th Session Indonesia. https://www.refworld.org/docid/59158ed24. html. Accessed 15 June 2021.

United Nations High Commissioner for Refugees (UNHCR). (2016c). Malaysia: Progress under the global strategy beyond detention 2014-2019, Mid-2016. Global Strategy Beyond Detention. https://www.unhcr.org/57b587617.pdf. Accessed 2 June 2021.

United Nations High Commissioner for Refugees (UNHCR). (2017). Information for Asylum-Seekers in Indonesia. https://www.unhcr.org/id/wp-content/uploads/sites/42/ 2017/05/Information-Leaflet-for-Asylum-Seekers-EnglishFeb-2017.pdf. Accessed 10 May 2021.

United Nations High Commissioner for Refugees (UNHCR). (2019a). Refugee movements in South East Asia. 2018 June 2019. https://www.unhcr.org/en-my/protection/ migration/5d91e2564/refugee-movements-south-eastasia-2018-june-2019.html. Accessed 25 June 2021.

United Nations High Commissioner for Refugees (UNHCR). (2019b). Rohingya Emergency. https://www.unhcr.org/ rohingya-emergency.html. Accessed 10 May 2021.

United Nations High Commissioner for Refugees (UNHCR). (2019c). UNHCR-WFP Joint Assessment Mission (JAM) Report 2019 Cox's Bazar, Bangladesh. Operational Data Portal (ODP). https://data2.unhcr.org/en/documents/ details/72273. Accessed 25 June 2021.

United Nations High Commissioner for Refugees (UNHCR). (2021a). Refugee Data Finder. https://www.unhcr.org/ refugee-statistics/. Accessed 1 July 2021. 
United Nations High Commissioner for Refugees (UNHCR). (2021b). South East Asia. Global Focus.https://reporting. unhcr.org/asia-pacific. Accessed 1 July 2021.

United Nations High Commissioner for Refugees (UNHCR). (2021c). Joint Government of Bangladesh - UNHCR Population Factsheet as of 31 March 2021. Operational Data Portal (ODP). https://data2.unhcr.org/en/documents/ details/86233. Accessed 20 June 2021.

United Nations High Commissioner for Refugees (UNHCR). (2021d). Thailand Fact Sheet 30 September 2021. https:// www.unhcr.org/th/en/unhcr-in-thailand. Accessed 1 November 2021.

United Nations High Commissioner for Refugees (UNHCR). (2021e). Indonesia: Monthly Statistical Report March 2021. https://www.unhcr.org/id/wp-content/uploads/sites/42/ 2021/04/Monthly-Statistical-Report-March-2021.pdf. Accessed 21 July 2021.

United Nations High Commissioner for Refugees (UNHCR). (2021f). Figures at a glance in Malaysia. https:// www.unhcr.org/en-my/figures-at-a-glance-in-malaysia. html. Accessed 1 July 2021.

United Nations Children's Fund (UNICEF). (2017). World's Second-Largest Oral Cholera Vaccination Campaign Kicks Off at Rohingya Camps in Bangladesh. https://www. unicef.org/press-releases/worlds-second-largest-oralcholera-vaccination-campaign-kicks-off-rohingya-camps. Accessed 15 May 2021.

United States Committee for Refugees and Immigrants. (2009). World Refugee Survey 2009 - Malaysia. http:// www.unhcr.org/refworld/docid/4a40d2adc.html. Accessed 15 May 2021.

Wake, C. \& Cheung, T. (2016). Livelihood Strategies of Rohingya Refugees in Malaysia: 'We Want to Live in Dignity'. HPG Humanitarian Policy Group Working Paper.

White, K. (2017). Rohingya in Bangladesh: an unfolding public health emergency. The Lancet 390: 1947. https://doi.org/ 10.1016/S0140-6736(17)32677-6

World Health Organisation (WHO). (2017). Mortality and Morbidity Weekly Bulletin (MMWB) Cox's Bazar, Bangladesh: Volume No. 8: 26 November - 2 December 2017. Reliefweb. https://reliefweb.int/report/ bangladesh/mortality-and-morbidity-weekly-bulletinmmwb-cox-s-bazar-bangladesh-volume-no-8-26. Accessed 2 February 2021.

World Health Organisation (WHO). (2018a). Help prevent malaria: WHO Myanmar newsletter special, September 2018. https://www.who.int/docs/default-source/searo/ myanmar/help-prevent-malaria-(english).pdf? sfvrsn=7e71af10_0. Accessed 20 February 2021.

World Health Organisation (WHO). (2018b). Bangladesh: Rohingya Refugee Crisis 2017-2018. Public Health Situation Analysis. https://reliefweb.int/sites/reliefweb. int/files/resources/public-health-situation-analysismay-2018.pdf. Accessed 25 May 2021.
World Health Organisation (WHO). (2019a). Measles. https:/ /www.who.int/news-room/fact-sheets/detail/measles. Accessed 20 February 2021.

World Health Organisation (WHO). (2019b). Dengue case management: From early recognition to recovery. https:// www.who.int/bangladesh/news/detail/01-10-2019dengue-case-management-from-early-recognition-torecovery. Accessed 20 February 2021.

World Health Organisation (WHO). (2020a). Rohingya Refugee Crisis - WHO Bangladesh Monthly Situation Report \#01, 30 January 2020. Reliefweb. https://reliefweb.int/report/ bangladesh/rohingya-refugee-crisis-who-bangladeshmonthly-situation-report-01-30-january-2020. Accessed 20 February 2021.

World Health Organisation (WHO). (2020b). Emergency: Rohingya Crisis - WHO Bangladesh Situation Report \#24, 24 September 2020 (Period Covered: Week 38: 14 September - 20 September 2020). Reliefweb. https:// reliefweb.int/report/bangladesh/emergency-rohingyacrisis-who-bangladesh-situation-report-24-24september-2020. Accessed 20 February 2021.

World Health Organisation (WHO). (2020c). World Malaria Report 2020. https://www.who.int/teams/global-malariaprogramme/reports/world-malaria-report-2020. Accessed 20 February 2021.

World Health Organisation (WHO). (2020d). Tuberculosis (TB). https://www.who.int/news-room/fact-sheets/detail/ tuberculosis. Accessed 20 February 2021.

World Health Organisation (WHO). (2021a). Rohingya crisis WHO Bangladesh situation report \#9, 14 May 2021 (Period covered: Weeks 17-18, 26 April-9 May). Reliefweb. https:/ /reliefweb.int/report/bangladesh/rohingya-crisis-whobangladesh-situation-report-9-14-may-2021-periodcovered-weeks. Accessed 25 May 2021.

World Health Organisation (WHO). (2021b). Dengue and severe dengue. https://www.who.int/news-room/factsheets/detail/dengue-and-severe-dengue. Accessed 20 February 2021.

Wong, D.T.K. (2013). The Cham arrivals in Malaysia: Distant memories and rekindled links. Archipel 85: 151-165.

Wong, Y.J. \& Lee, S.W.H. (2020). Prevalence of latent tuberculosis among refugee children in Malaysia. ERJ Open Research 6: 00254-2019. https://doi.org/10.1183/ 23120541.00254-2019

Yunus, R.M., Azme, N., Chen, X.W., Badlishah-Sham, S.F., Miptah, H.N. \& Azraai, A.M. (2021). The need to map existing health care services for refugees in Malaysia. Journal of Global Health 11: 03024. https://doi.org/10.7189/ jogh.11.03024

Zarni, M. \& Cowley, A. (2014). The slow-burning genocide of Myanmar's Rohingya. Pacific Rim Law \& Policy Journal 23: 682-752. 